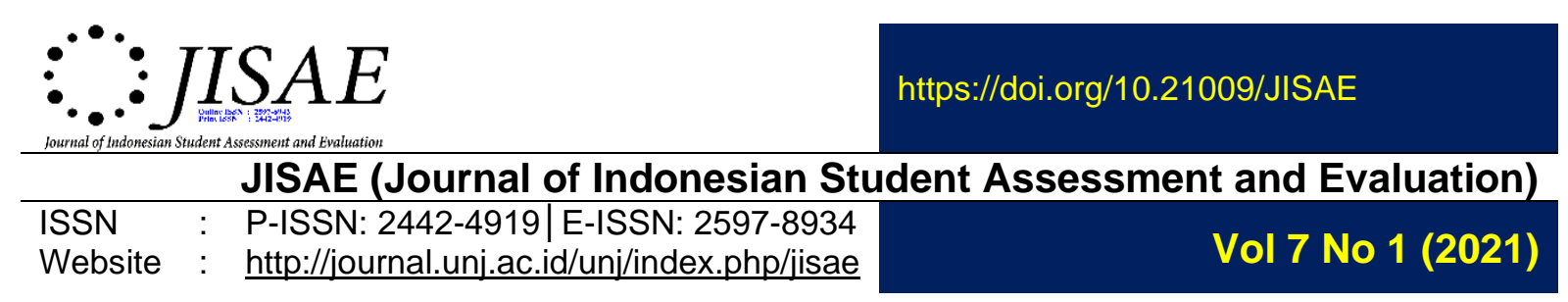

\title{
ASSESSMENT OF SOCIAL ATTITUDES DURING ONLINE LEARNING USING WHATSSAPP
}

\section{Ristasari Oktavia ${ }^{1}$ \\ Natural Science Study Program Tarbiyah and Tadris Faculty Bengkulu State Islamic Institute - Indonesia 65144}

\section{Nurul Khotimah ${ }^{2}$ \\ Natural Science Study Program Tarbiyah and Tadris Faculty Bengkulu State Islamic Institute - Indonesia 65144}

\section{Ade Pratama Putra ${ }^{3}$}

Natural Science Study Program Tarbiyah and Tadris Faculty Bengkulu State Islamic Institute Indonesia 65144

\section{Ahmad Walid ${ }^{4}$ \\ Natural Science Study Program Tarbiyah and Tadris Faculty Bengkulu State Islamic Institute - Indonesia 65144}

Address for Correspondence: srista784@gmail.com

\begin{abstract}
The purpose of this research is to obtain a description of students' social attitudes in learning activities on WhatsApp media. This research is a quantitative study using a survey method. The sample that the researchers took themselves were tadris science students class 2018. The instrument provided was a questionnaire distributed in the form of google form. This is done in order to make it easier for objects to access them. The results of research that have been carried out on the social attitudes of the 2018 science tadris study program students which include honesty, discipline, caring for each other, responsibility and courtesy can be categorized as quite good.
\end{abstract}

Keywords: Social Attitude, Learning, Online, WhatsApp

\section{INTRODUCTION}

The results of the learning process are often measured only from the level of knowledge competency attainment that has been achieved by students. However, this is not sufficient to become a benchmark for educational success. Therefore, attitudes, spiritual competence and skills are also important to measure the level of success.

Based on the 2013 curriculum, attitude competence consists of spiritual attitudes and social attitudes. Social attitude is the awareness of individuals to find real actions towards social objects or those related to socializing with society (Ahmad, 1998). A student with a high positive attitude shows a high academic level (Nolandkk, 2012). Social attitudes that can be assessed based on the competence of social attitudes are responsible behavior, respect for others, honesty, democracy and wisdom (Compiler Team, 2013). Assessment of social attitudes can be expressed as an assessment of students' attitudes which are shown through the actions of students towards the 
learning process and certain values that are implanted through certain materials (Majid, 2007).

Learning is a complex aspect of human activity, which cannot be fully explained. Learning can be defined as a product of continuous interaction between development and life experiences. Learning in a complex meaning is a conscious effort from a teacher to teach students (directing student interaction with other learning sources) in order to achieve the expected goals (Trianto, 2010). The learning process is a systematic effort by the teacher to realize the learning process runs effectively and efficiently, starting from planning, implementation and evaluation (Aqib, 2013). On the basis of the learning theory according to the experts above, it can be concluded that learning is a process of interaction between students and tutors and their environment as well as all other learning resources that become learning tools in order to achieve the desired goals in order to change attitudes and mindsets learners.

In 2020, the world will experience the Covid-19 pandemic, which forces the world to make changes in an effort to break the chain of transmission, including the education system. The government is trying to maximize the learning process to keep it running, until online learning is held.

The online learning system (in a network) is a learning system without face-toface learning between teachers and students but is done online using the internet network. Teachers must ensure teaching and learning activities continue, even though students are at home. The solution, teachers are required to be able to design learning media as an innovation by utilizing online media (online). This is in accordance with the Minister of Education and Culture of the Republic of Indonesia regarding Circular Number 4 of 2020 concerning Implementation of Education Policies in an Emergency for the Spread of Corona Virus Disease (COVID-19).

The learning system is implemented through a personal computer (PC) or laptop connected to an internet network connection. Teachers can learn together at the same time using groups on social media such as WhatsApp (WA), telegram, Instagram, zoom applications or other media as learning media. Thus, the teacher can ensure students take part in learning at the same time, even in different places. The online learning process will run well, if the learning process is supported by learning media. Learning media is a learning process aid that is used to stimulate the thoughts, feelings, attention and abilities or skills of students. This learning media is held as a tool in the learning process. One of them is the WhatsApp application.

WhatsApp is an instant messaging application for smartphones, when viewed from its function WhatsApp is almost the same as the SMS application that you usually use on old cellphones. But WhatsApp doesn't use credit, but internet data. So, in this application, you don't have to worry about the length of the characters. WhatsApp users, which were originally created for iPhone users, are now also available for BlackBerry, Android, Windows Phone and Symbian versions. Whatsaap is one of the learning media because it has a feature to create message groups, by utilizing this feature teachers and lecturers can monitor students during learning. As a teacher or lecturer, they are required to be creative and innovative in carrying out their duties. So now many have used social media to support learning activities. Like in school, students have used social media to communicate with other friends. This also makes teachers and lecturers have to take advantage of social media in the classroom such as making WhatsApp groups to support student learning activities to be more active and useful in using gadgets. The purpose of this research is to obtain a description of the social attitudes of students in learning activities on WhatsApp media. 


\section{METHOD}

This research is a quantitative research. Quantitative research seeks to reveal universal truths and principles in the form of relationships between variables or phenomena (Nenty, 2009). The characteristic of quantitative research is that the data analysis technique uses quantitative techniques (statistics) objectively (Creswell, 2010). This research refers to the assessment of students' social attitudes in learning activities on the WhatsApp media.

Researchers used a survey method. Survey research is seen as a method to describe quantitatively specific aspects of a particular population so that data collection is carried out on a group of people whose results can be generalized back into a particular population (Pinsonneault \& Kraemer, 1993). This method can be used to find out the value of student attitudes during online learning during the Covid-19 pandemic. The sample that the researchers took was the 2018 natural science tadris students. The instrument provided was a questionnaire distributed in the form of a google form. This is done in order to make it easier for objects to access them.

The survey data made aims to find out how the assessment of student attitudes during online learning, while the type of survey uses a Likert scale. The Likert scale is used to measure attitudes, opinions and perceptions of individuals or groups of people towards social phenomena (Sugiyono, 2018). The Likert scale table is presented below.

Tabel 1. Liert Scale

\begin{tabular}{|c|c|}
\hline Assessment criteria & Assestment Scale \\
\hline Strongly agree & 5 \\
Agree & 4 \\
Netral & 3 \\
Disagree & 2 \\
Strongly Disagree & 1 \\
\hline
\end{tabular}

Meanwhile, the data analysis technique in this study was carried out by calculating the percentage of the scores that have been obtained, while the formula for calculating the percentage is as follows.

Index formula \% $=(\mathrm{T} \times \mathrm{Pn} / \mathrm{Y}) \mathrm{X} 100$

The percentage results that have been obtained are interpreted by the scores based on the following interval table.

Tabel 2. Score Interpretation Criteria

\begin{tabular}{|c|c|}
\hline Assestment Criteria & Information \\
\hline $0 \%-19,99 \%$ & Not Very Good \\
\hline $20 \%-39,99 \%$ & Not Good \\
\hline $40 \%-59,99 \%$ & Netral \\
\hline $60 \%-79,99 \%$ & Good \\
\hline
\end{tabular}


The results of the calculations above are the basis for analyzing in depth and concluding how the social attitudes of the 2018 IAIN Bengkulu Science students in participating in online learning.

\section{RESULT AND DISCUSSIONS}

Assessment of social attitudes is important in supporting successful learning in the cognitive and psychomotor domains. Students who have a positive attitude towards a lesson are expected to achieve optimal learning outcomes (Stiggins, 1994). Lack of attention to social attitudes causes problems in the emotional intelligence of students (Darmansyah, 2014). Students' social attitudes can be seen from how the interactions that occur between each other. The attitudes that exist in students can be in the form of discipline, honesty, courtesy, care for each other and responsibility.

Social development consists of three interrelated processes, namely learning to behave socially acceptable to play an acceptable social role, and liking people and social activities (Hurlock, 2000). Social attitude is a predisposition or tendency to behave in a certain way towards other people. In addition, it can be interpreted as an attitude that is directed towards social goals, as opposed to an attitude that is directed towards personal goals (J.P. Chaplin, 2006).

Online learning began in March 2020 as an effort to prevent the transmission of Covid-19. This means that the 2018 class of science tadris study program has undergone online learning from the semester and continues until the 5th semester. Researchers have distributed a questionnaire in the form of a google form to students of the 2018 class of science tadris class. Counting 30 students filled out the questionnaires that had been distributed. The following is the table of the results of the calculation of the attitude assessment survey during online learning in the science tadris study program, batch 2018:

Tabel 3. Percentage of Social Attitudes Assessment

\begin{tabular}{clcc}
\hline Indikator & \multicolumn{1}{c}{ Aspek } & Persentase & Kriteria \\
\hline Kejujuran & $\begin{array}{l}\text { Mengerjakan Tugas dengan } \\
\text { Jujur, baik dan benar }\end{array}$ & $66,6 \%$ & Baik \\
& $\begin{array}{l}\text { Tidak mencontek jawaban } \\
\text { teman }\end{array}$ & $69,3 \%$ & Baik \\
& $\begin{array}{l}\text { Melakukan absensi tepat } \\
\text { waktu }\end{array}$ & $77,3 \%$ & Baik \\
& $\begin{array}{l}\text { Memperhatiakn } \\
\text { penyamapaian dan } \\
\text { penjelasan materi } \\
\text { Mengikuti pembelajarn }\end{array}$ & $65,3 \%$ & Baik \\
& $\begin{array}{l}\text { sampai selseai } \\
\text { Mempelajari materi yang } \\
\text { dibagikan teman dan dosen }\end{array}$ & $80,6 \%$ & Sangat Baik \\
Peduli antar & $\begin{array}{l}\text { Membantu teman dalam } \\
\text { selajar dan berdiskusi }\end{array}$ & $70,6 \%$ & Baik \\
\hline Tanggung jawab & $\begin{array}{l}\text { Mengkuti diskusi dengan baik } \\
\text { dan benar }\end{array}$ & $78,6 \%$ & Baik
\end{tabular}




\begin{tabular}{|c|c|c|c|}
\hline Indikator & Aspek & Persentase & Kriteria \\
\hline & $\begin{array}{l}\text { Mengkuti Pembelajaran } \\
\text { tanpa melakukan kegiatan } \\
\text { lain }\end{array}$ & $51,3 \%$ & Cukup \\
\hline & $\begin{array}{l}\text { Bekerja sama dengan } \\
\text { kelompok dalam } \\
\text { mengerjakan tugas kelompok }\end{array}$ & $85,3 \%$ & Sangat Baik \\
\hline & $\begin{array}{l}\text { Tanggung jawab dengan } \\
\text { tugas yang telah diberikan }\end{array}$ & $86,6 \%$ & Sangat Baik \\
\hline \multirow[t]{3}{*}{ Sopan Santun } & $\begin{array}{l}\text { Mengucapkan salam dan } \\
\text { menjawab salam }\end{array}$ & $81,3 \%$ & Sangat Baik \\
\hline & $\begin{array}{l}\text { Tidak membuat keributan } \\
\text { selama pembelajran }\end{array}$ & $70,6 \%$ & Baik \\
\hline & Menghormati orang lain & $80 \%$ & Sangat Baik \\
\hline
\end{tabular}

Referring to the results of research based on table 3, the value of social attitudes is very important in the learning process. Honest attitude is behavior that is based on an effort to make himself a person who can always be trusted in his words, actions and work (Curriculum, 2013). Students must be honest in carrying out learning. The assignment that has been given by the lecturer must be done honestly, well and correctly. Students have carried out their assignments honestly, well and correctly. This must be increased so that the learning outcomes obtained can be maximized.

Learning during the covid-19 pandemic is carried out online or online. But learning still has to be disciplined. Discipline attitude influences students to obey the rules or not. When the existing rules are related to social attitudes, this disciplinary attitude affects students' social attitudes. Rules related to disciplinary attitude include not arriving late, attending lessons on time, not leaving lessons during learning, asking for permission when there is a need, and doing assignments on time. The main function of discipline is to teach the child to receive the restraint necessary to help mobilize the child's energy into a path that is useful and socially acceptable (Hurlock, 2000). Discipline is an action that shows orderly behavior and obeys various rules and regulations (Muhammad Fadhillah, 2013). So the rules or regulations that have been made must be obeyed.

Students have carried out the rules that have been conveyed by the lecturer for each subject at the first meeting at the beginning of the semester. For example students are not late when filling absences before starting learning, paying attention to material explanations and discussions during the learning process, and also do not leave online classes until learning ends.

A caring attitude between each other is needed to collaborate with friends or group members and other people. An important character that must be built so that students can achieve success, both at school and after graduating, is the ability to collaborate with their friends and others (Jamal Ma'mur Asmani, 2012). This Siakp is needed to build a person's cooperation with friends and group members. According to the Big Indonesian Dictionary, empathy is a mental state that makes a person feel or identify himself in a state of feeling or mind that is the same as another person or group. Students are able to socialize well even though learning is carried out online. It can be seen from how students help each other in solving problems that occur during the learning process. Besides that, the attitude of helping to help is also related to caring for each other. An attitude of help can provide guidance to do good with the 
heart (Lickona, 2012). This is what encourages us to be able to help each other in solving ethical problems and responsibilities that apply widely.

As social beings, of course we also have rights and obligations. With this obligation we are required to be responsible for all the demands that have been given. Responsibility, namely the attitude and behavior of a person to carry out their duties and obligations, which should be done to oneself, society, the environment, the country and God Almighty (Curriculum, 2013). The value of respect and responsibility is the basis of the main morality that applies universally (Lickona, 2012). Responsibility cannot be separated from something that must be carried out and implemented with the values that are bound in it (Arismantoro, 2008).

The form of the responsibility attitude that has been carried out by students includes following discussions well, carrying out tasks seriously, participating in learning without doing other activities that can interfere with the learning process, participating in working on group tasks and being personally responsible for the tasks that are carried out. has been given by lecturers both individually and in groups. Even though lectures are conducted online, students still have to fulfill their responsibilities.

Learning carried out online still must pay attention to ethics in learning. One of them is courtesy. Polite and courteous are rules or procedures that have been developed from generation to generation in a culture in society that can be useful in the interaction between humans so that a close relationship, mutual understanding and respect for each other is established (Taryani in Suharti, 2004). Polite attitude is an obligation that must be done by every human group, from children to parents as well as students.

The students had good manners. Students continue to give and answer greetings every time they start and end learning to both lecturers and classmates, as long as learning does not make a fuss that can interfere with the learning process, and also respect each other's attitude and way of speaking. From the questionnaire data, $80 \%$ of students had said and answered greetings from lecturers and classmates, $70 \%$ of students also did not make a fuss, and $86 \%$ showed mutual respect.

Based on the results of research that has been carried out on the social attitudes of the 2018 science tadris study program students which include honesty, discipline, caring for each other, responsibility and courtesy can be categorized as quite good. The positive attitudes that continue to be developed have a good impact on ourselves, society, the environment, the country and God Almighty so that we can be accepted as members of social groups. A positive social attitude is very important in the learning process. This positive attitude makes a person able to improve the quality of learning and good learning achievement. So from that we must avoid negative attitudes because it will have an impact on the learning process and results that are getting lower.

\section{CONCLUSSION}

Thus, based on the research that has been done, it can be concluded that during the Covid-19 pandemic, learning was carried out online or in a network via WhatsApp media, WhatsApp has also become one of the media that is quite easy to use, making it easier for students and lecturers to carry out learning.

During the learning process using WhatsApp, students showed a fairly good social attitude, these social attitudes included honesty, discipline, caring for others, courtesy and responsibility. In learning this social attitude is very necessary to improve the quality of learning and get good learning achievement. 


\section{REFERENCES}

Abdul Majid.2007.Perencanaan Pembelajaran.Bandung:PT Remaja Rosdakarya Ahmad, Dkk.1998.Pembangunan Kurikulum.Bandung:CV Pustaka Setia

Aqib, Zainal.2013.Model-model, Media, dan Strategi Pembelajaran Konstektual (Inovatif).Bandung: Yrama Widya.

Arismantoro.2008. Tinjauan Berbagai Aspek Charachter Building:Bagaimana Mendidik Anak Berkarakter.Yogyakarta:Tiara Wacana

Asmani, Jamal Ma'mur.2012. Buku Panduan Internalisasi Pendidikan Karakter Disekolah. Yogyakarta:Diva Press

Creswell, J.w.2010.Research design:Pendekatan Kualitatif, Kuantitatif dan Mixed. Yogyakarta: PT Pustaka Pelajar

Darmansyah.. 2014. Teknik Penilaian Sikap Spiritual dan Sosial dalam Pendidikan Karakter di Sekolah Dasar 08 Surau Gadang Nanggalo. Jurnal Al-Ta'lim Universitas Negeri Padang.

Fadilah, Muhammad dan Lilif Mualifatu Khorida. 2013. Pendidikan Karakter Anak Usia Dini. Jogjakarta: Ar-Ruzz Media

H. Johnson Nenty.2009.Research Orientation and Research-Related Behaviour of Graduate Education Student:Journal of Social Sciences

Hurlock, Elizabeth B. 1978. Child Development (ter. Med Meitasari Tjandrasa). New York: Mc Graw Hill

Pinsonneault, A \& Kraemer, K.1993.Research Methodology in Management Information System. Journal of Management Information System-Special Section:Starategic and Competitive Information System Archive,10,75-105.

Stiggins, R.J.1994. Student Centered Classroom Assesment. Mac Milan College Publishing Company. New York

Suharti. 2004. Pendidikan Sopan Santun dan Kaitannya Dengan Perilaku Berbahasa Jawa Mahasiswa: Universitas Negeri Yogyakarta

Thomas, Lickona.2012.Character Matter. Jakarta:PT. Bumi Aksara

Tim Penyusun.2013.Kerangka Dasar dan Struktur Kurikulum Sekolah Menengah Atas/Madrasah Aliyah. Jakarta:Kemendikbud 